\title{
FINANCIAL INSTITUTIONS' CRITERIA AND MECHANISMS IN FINANCING SMALL AND MEDIUM ENTERPRISES IN PLATEAU STATE, NIGERIA
}

\author{
Joshua Solomon Adeyele* \\ Department of Actuarial Science, University of Jos, Nigeria
}

The inability of small and medium enterprises (SMEs) to access funds from financial institutions has been identified as one of the major problems limiting their expansion horizons. This study assesses the criteria and mechanisms used by financial institutions when granting loans to SMEs. The data were sourced from the relevant financial institutions and analyzed by using different statistical tools. One of the findings revealed that the financial ratio and the internal control system accounted for $28.7 \%$ of the part of the conditions for granting loans to SMEs. Similarly, good working capital and the ease of asset conversion accounted for $94.5 \%$ of the criteria used by financial institutions to extend credits/loans to SMEs. Also, the educational background of SMEs' operators significantly influenced the financial institutions' choice of SMEs to finance. Based on these findings, the study recommends that there is a need for SMEs' operators to align their business activities with financial institutions' lending criteria.

Keywords: small and medium enterprises, liquidity ratio, internal control system, loan access, financial institutions

JEL Classification: G21, H81

\section{INTRODUCTION}

In attempts to industrialize Nigeria's economy, the Federal Government of Nigeria has mainly been focused on the development of small and medium enterprises (hereinafter referred to as SMEs) since the change from the military rule to the present democratic dispensation. This has been demonstrated not only in policy statements and the formulated policy measures,

* Korespondencija: J. S. Adeyele, Department of Actuarial Science, University of Jos, Nigeria;

e-mail: adesolojosh@gmail.com but also and especially in the establishment of the Small and Medium Enterprises Development Agency of Nigeria (SMEDAN) (Iyortsuun, 2017). In spite of the roles played by SMEs in creating employment opportunities, thereby militating against the ruralurban drift, and mobilizing local resources, as well as the stimulation of technological development, their survival in emerging economies is being constrained due to their peculiar characteristics. This has led to the gross underperformance of the SMEs subsector and their contributions to economic growth and development are very low. 
The high risk of SMEs has been noted to threaten their survival more frequently than that of largescale enterprises (Bank of England, 2001; Bamfordt \& Bruton, 2006; Adeyele \& Omorokunwa, 2016). While this is arguably true to some extent, not many studies of SMEs financing have investigated how SMEs should be packaged in a form financial institutions will be willing to finance. In order to understand how to address SMEs' lack of access to funds, there is a need to understand the significant role of the capital structure, the age of a business, and the internal control system from financial institutions' point of view, rather than solely relying on reports drafted by SMEs' owners.

The willingness demonstrated by financial institutions to extend a credit facility to SME businesses is contingent to a careful assessment of SMEs' business viability through a financial report. Various mechanisms are employed by financial institutions in order to determine whether to grant loans to SME businesses, including their capital structure. However, the capital structure of SMEs has been a barrier in the sense that, for many times, records for the basis of the assessment by financial institutions are not kept by SMEs' operators. This inability of lenders to assess the credit worthiness and the asset liquidity of SMEs partly explains the reasons why SMEs' operators run into a financial crisis. The International Labor Organization - ILO (2013) reveals the fact that each year the problems of substandard products and services, as well as difficulties in marketing these products and services, lead a great number of SMEs to a bankruptcy. This suggests that, during a crisis period, there is a need for SMEs' owners to devise strategies so as to monitor current expenses and predict the likely future costs that could emanate from risky actions.

When considering business risks, SMEs usually rely on financial factors such as sales or a profit (Waring \& Glendon, 1998). The creation of a new business venture involves a thorough understanding of the entrepreneurial process. This process can only be achieved through the capacity training that enables business owners to design the right network that overcomes the strong forces that every new business venture is faced with. It is expected that if an increase in the training capacity is reduced to practice, it will improve strategies for accessing funds for SME businesses. Consequently, this study is designed to explore how skill acquisition by SMEs operators and the capital structure can help them to effectively network their businesses from the point of view of financial institutions.

Based on the foregoing, the main aim of this study is to examine the criteria and mechanisms used by financial institutions in making decisions on granting loans to SMEs in Jos Metropolis, whereas the specific objectives of the study are: to determine the impact of the age of a business, the financial ratio, and the internal control system as a condition for granting a loan to SMEs; to investigate the influence of good working capital and the liquidity of an asset on SMEs' financial ratio, which financial institutions take into consideration when deciding on financing SMEs in Jos Metropolis; to find out whether the financial ratio and the Education/Vocational training jointly have a significant impact on SME financing; to examine the interrelationship between the financial ratio, a shortterm credit collection, good working capital and the liquidity ratio; and to investigate whether access to bank loans by SME businesses significantly varies with financial institutions.

The corresponding hypotheses for this study are stated in an alternate form and are tested at the 0.05 level of significance, which includes the following:

H1: The age of a business, the financial ratio, and the internal control system have a significant impact on the condition for granting a loan to SMEs.

H2: Good working capital and the liquidity of an asset significantly influence the SMEs' financial ratio that financial institutions take into consideration in financing SMEs in Jos Metropolis.

H3: The financial ratio and Educational/Vocational training have a significant impact on SME financing. 
H4: There is a significant interrelationship between the financial ratio, a short-term credit collection, good working capital and the liquidity ratio.

H5: Access to bank loans by SME businesses varies significantly with financial institutions.

These hypotheses are also restated in the methodology section, alongside the model specifications and the required statistical tools for testing them. This study covers all the commercial banks, as well as the bank of industry and microfinance banks in Jos, the capital city of the Plateau State of Nigeria. This is an investigative approach from the point of view of financial institutions with respect to the qualities they expect SMEs to have prior to extending credit facilities to them. The paper is divided into the subsequent: Section two deals with a review of the relevant literature on SMEs financing. Section three is concerned with the scientific instrumentations used in the research process, whereas the results for the study are presented in Section four. The final section contains the conclusion and the recommendations.

\section{LITERATURE REVIEW}

New concepts development - The terms SME financing and SMEs' access to a loan are often used interchangeably in order to imply how business owners or managers obtain loans or raise funds from creditors or financial institutions so as to conduct the affairs of their companies or businesses. In other words, raising funds from whatever means or sources for the purpose of maintaining business continuity could imply business financing. While the two terms have not been challenged, nor have they generated any controversy in the literature, the researcher attempts to use them in a different sense. In this study, the term SME financing is used to imply a form of empowerment programs put in place by financial institutions in order to support government policies on the development of SMEs.

Financial institutions do not collect funds from the general public just for the purpose of safekeeping; they also invest these funds in profitable ventures by lending to business owners at interest rates. As a part of their subsidiaries, they can even start and develop small businesses to medium-sized ones by financing the activities of their businesses directly or indirectly where they extend a credit to the SMEs that present a business proposal/feasibility studies they believe will generate high returns. This type of a credit facility does not require collateral securities because they (financial institutions) will have an opportunity to monitor and supervise how the businesses they finance are managed. The monitoring of and supervision rights of financial institutions to SME businesses will be derived from the conditions for extending a credit facility. However, in a situation where business owners deliberately approach financial institutions for a credit facility, there are some requirements or qualities the business in question needs to have before loans can be granted. This type of a credit facility can be termed SMEs' access to a loan. Where business owners seek loans from financial institutions, the lender will assess the borrower's credit worthiness through the inspection and analysis of debt items, loan balances and repayment track records (Haron, Said, Jayaraman \& Ismail, 2013). If such lenders are satisfied with the information sought, they will grant a loan.

Financial institutions can also use the existing debt and debt application balances in the borrower's financial reports so as to determine the extent of the borrower's indebtedness (Haron et al, 2013). The financial crisis that took place in 2008/2009 has forced many financial institutions to take precautions on how they lend out funds to borrowers, which has led to complexities in credit processing. It should be noted that in accessing funds from banks or financial institutions by pledging assets as a form of collateral security before such funds have been released to them they will be faced with a default because a great majority of them only lease and do not own their own building which they operate from.

In terms of poverty alleviation, SMEs have significantly contributed to the development of economies worldwide, being the largest sector generating emplacement even though they lack the capacity to expand their business activities. 
For example, in developed countries, especially in Europe, SMEs have been reported to be playing a consistent leading role in the growth of the European economy, constituting more than $98 \%$ of all the businesses, generating $67 \%$ of the total employment, and $58 \%$ of the gross value added in 2012. Similarly, in developing countries, SMEs also play a vital role by contributing up to $45 \%$ of employment, as well as 33\% of the annual GDP (Nguyen \& Luu, 2013).

A. R. Kira (2013) revealed the fact that SMEs' financing difficulties restrict their investment opportunities and slowdown their growth. It was also noted that access to finance is broadly seen as an essential determinant for firms, particularly for SMEs, to effectively run their daily business operations, with the goal of achieving long-term investment opportunities and development targets (Kira, 2013). SMEs usually finance a larger portion of their business outside formal means, such as relations, the family and friends, or mainly rely on short-term financing. This result is in agreement with the theoretical models that applied fixed transaction costs and information asymmetries, and the resulting agency problems as the basis for the financial market conflicts (Nguyen \& Luu, 2013). Due to small firms' size and ownership structure that indicate a higher credit risk, the financial institutions which are riskaverse are usually less motivated to extend a credit to SMEs. That is why many of them rely on informal means.

Access to a loan - SMEs are also perceived as lacking in meeting the requirements needed for the formal source of financing (Beck, Demirgüç-Kunt, Laeven \& Maksimovic, 2006; Singh \& Janor, 2013). A lack of access to formal means of financing businesses has been reported as the critical element that hinders SMEs' development (Kira, 2013). However, H. Haron et al (2013), noted that, apart from good financial records, accessing bank loans also requires a good rapport with lenders. Commercial banks predominantly earn their profit through lending (Asantey \& Tengey, 2014) and also serve as a means of financing many businesses, SMEs in particular, which solely depend on the traditional debt in order to fulfill their business financial needs. Credit risk generates a possibility of SMEs potential defaulting on the principal and interest repayment obligations (Obamuyi, 2007). Thus, in order to extend a credit to SMEs, commercial banks' decision on lending is often based on the strength of the audited financial statements, long credit histories and a good record of the principal owner, most of which are not found in SMEs. Despite the fact that financial institutions have identified SMEs as fast-growing entities, there are several limitations representing a barrier to SMEs in their accessing funds from financial institutions (Shikumo \& Mwangi, 2016).

In an attempt to determine the most crucial factor affecting SMEs' performance, many studies have come to a conclusion that a lack of access to funds plays a dominant role due to high transaction costs, which prevents SMEs from obtaining a credit more than it does larger enterprises (Saito \& Villanueva, 1981), together with the information asymmetries associated with SMEs (Beck \& Demirguc-Kunt, 2006; Kira, 2013). B. Levy (1993) noted that the nonavailability of funds to finance working capital was a part of the constraints that limit SMEs' expansions. This limitation may not be unconnected with owners' experience and education/training. A study by J. Rand (2007) found a negative association between one's being highly or moderately skilled, on the one hand, and accessing a credit, on the other, reflecting that owners with higher skill levels have lower demand for debts and finance themselves from within internal funds, or that better-educated and better-experienced SMEs' owners are more likely to know when their application will be rejected, and therefore refrain from applying. Another study by V. Thanh, T. T. Cuong, B. Dung \& T. D. U. C. Chieu (2011) also finds that a firm owner's experience and education of SMEs' owners/operators play a significant role in reducing a probability of a bank loan being rejected.

The age of a firm has also been reported to influence financial institutions' choice of credit financing in many studies (Nguyen \& Luu, 2013), as young enterprises, especially start-ups, are likely to seek finance from informal sources, whereas the older ones have more advantages in searching for bank debts or equity. However, J. Rand (2007) finds a negative relation between the age and the holding of debts by 
arguing that old firms are usually more settled and less likely to engage in risky activities.

SMEs financing - The studies of the determinant of SMEs' financing at both the local and the international levels have been conducted (Shikumo \& Mwangi, 2016). In a study by D. G. K. Agyapong and K. Darfor (2011), the criteria for assessing SMEs' borrowers in Ghana were examined. The study revealed that credit managers made decisions on whether to accept or reject a loan application submitted by SMEs based on the previous loans repayment history, the repayment schedule, the type of the business activity involved, the loan size relative to the business. Based on the revealed literature, the subsequent section is dedicated to the detailed methodological approach employed.

\section{DESIGN AND METHODOLOGY}

Financial institutions, such as banks, play a significant role in the growth and survival of SMEs in any economy. Because of this crucial role, this study used banks, including the Bank of Agriculture and the micro-finance banks in Jos Metropolis. Hence, the population for this study is all the commercial banks, as well as the bank of industry and the microfinance banks in the study area. In this study, the primary data sourced from the employees working at the loans and credits departments of the selected banks are made use of. In order to access the respondents, the secretaries of the selected banks were contacted and asked for a permission to distribute the questionnaire. The copies of the questionnaire were distributed to the selected banks and subsequently retrieved from the respondents. The questionnaire consisting of both the closed and the open-ended questions seeking qualitative and quantitative responses from the selected banks in order to test different research hypotheses was applied in the study. All the question items in the questionnaire are based on the conditions under which banks will be willing to lend funds to SMEs if such requirements are met by the applying SMEs' operators in Jos Metropolis. Purposive random sampling was used to select 100 respondents from the financial institutions.
Model Specification - As a sequel to the review of the related literature, and in line with the specific objectives of the study, the following hypotheses and corresponding models have been developed:

According to the reviewed literature, it is clear that a good internal control system will lead to good financial ratios, which can easily be achieved by the SMEs that have been operative for a number of years, differently from those newly-emerged. With these criteria in place, it is proposed that all these variables directly or indirectly influence some of the conditions for granting loans to SMEs. Hence, the researcher hypothesized that:

H1: The age of a business, the financial ratio, and the internal control system have a significant impact on the condition for granting a loan to SMEs. The model required for this hypothesis is given as follows:

$$
\operatorname{ConBL}=(A O B, \text { FinR }, I C S)
$$

Stochastically,

$$
\operatorname{Con} B L=\lambda_{0}+\lambda_{1} A O B+\lambda_{2} \operatorname{FinR}+\lambda_{3} I C S+\varepsilon(1 \mathrm{~b})
$$

where:

ConBL - Condition for bank lending,

$A O B$ - Age of Business,

FinR - Financial ratio,

ICS - Internal control system,

$\varepsilon$ - error term,

$\lambda_{0}$ is the intercept; $\lambda_{1}$ to $\lambda_{3}$ represent coefficient of the variables measured.

A good financial ratio achieved through good working capital and the ease of asset conversion to cash is suspected to have a close connection with a financial institution's decision to extend a credit facility to SMEs. Therefore, it is hypothesized that: 
H2: Good working capital and the liquidity of an asset significantly influence the SMEs' financial ratio that financial institutions take into consideration when financing SMEs in Jos Metropolis. The model for this hypothesis is given as follows:

$$
\text { SMEfinR }=(\text { Gwkg, SMEloa })
$$

$$
\text { SMEfinR }=\lambda_{0}+\lambda_{1} G w k g+\lambda_{2} \text { SMEloa }+\varepsilon
$$

where:

SMEfinR - SMEs Financial ratio,

Gwkg - good working capital,

SMEloa - SMEs Assest Liquidity,

$\varepsilon$ - error term,

$\lambda_{0}$ is the intercept; $\lambda_{1}$ to $\lambda_{2}$ represent coefficient of the variables measured.

To compliment Model (2), it is reasonable that, if financial institutions pay close attention to the financial ratio of SMEs before granting them a loan, then a good understanding of the business undertaken by such SMEs' owners/operators can serve the purpose as well. Based on this, the hypothesis for achieving the objective is given as follows:

H3: The financial ratio and Educational/Vocational training have a significant impact on SMEs financing.

$$
\text { SMEfin }=(\text { FinR }, \text { EduVoc })
$$

Stochastically,

$$
\text { SMEfin }=\lambda_{0}+\lambda_{1} \text { FinR }+\lambda_{2} E d u V o c+\varepsilon
$$

where:

SMEfin - SMEs financing criteria,
FinR - SMEs financing ratio,

EduVoc - Education/Vocational training,

$\varepsilon$ - error term,

$\lambda_{0}$ is the intercept; $\lambda_{1}$ to $\lambda_{2}$ represent coefficient of the variables measured.

The other hypotheses of the study - The two remaining hypotheses not subject to the linear and multiple regressions models were tested by applying inferential statistics. These hypotheses are:

H4: There is no significant interrelationship between the financial ratio, a short-term credit collection, good working capital and the liquidity ratio.

H5: Access to bank loans by SME businesses does not significantly vary with financial institutions.

The hypothesis (H4) was tested by applying the partial correlation, whereas the hypothesis (H5) was tested by applying the Analysis of Variance (ANOVA).

\section{RESULTS}

Descriptive analysis - Table 1 shows the demographic information about the respondents including their gender, age, educational qualification, and work experience. It shows that the majority of the respondents $(64.8 \%)$ have worked in finance-related companies for over a period of 6 to 17 years: 6-11 $(31.9 \%)$ and $12-17(22.3 \%)$. Most of the workforce age brackets fall within the age of 31-40 (46.8\%), whereas the respondents within the age brackets of 21-30 and $41-50$ account for $29.8 \%$ and $18.1 \%$, respectively. The percentage of the male to the female respondents ranges from $51.1 \%$ to $48.9 \%$. All this information has an implication for SME businesses because the younger age among banks' staff indicates a larger number of years to be spent in the bank and these groups of people are likely to be the same people who will be making important decisions when SMEs' owners come to their banks to ask for loans after having met the requirements attractive to lenders. 
Table 1 Demographic Information

\begin{tabular}{|c|c|c|c|c|c|}
\hline \multicolumn{2}{|c|}{ Gender } & \multirow{2}{*}{$\begin{array}{c}\begin{array}{c}\text { Frequ- } \\
\text { ency }\end{array} \\
46\end{array}$} & \multirow{2}{*}{$\begin{array}{c}\text { Percent } \\
48.9\end{array}$} & \multirow{2}{*}{$\begin{array}{c}\begin{array}{c}\text { Valid } \\
\text { Percent }\end{array} \\
51.1\end{array}$} & \multirow{2}{*}{$\begin{array}{c}\begin{array}{c}\text { Cumul- } \\
\text { ative } \\
\text { Percent }\end{array} \\
51.1\end{array}$} \\
\hline \multirow{3}{*}{ Valid } & Male & & & & \\
\hline & Female & 44 & 46.8 & 48.9 & 100 \\
\hline & Total & 90 & 95.7 & 100 & \\
\hline \multirow{3}{*}{$\begin{array}{l}\text { Missing } \\
\text { Total }\end{array}$} & System & 4 & $4 \cdot 3$ & & \\
\hline & & 94 & 100 & & \\
\hline & $21-30$ & 28 & 29.8 & 31.5 & 31.5 \\
\hline \multirow{3}{*}{$\begin{array}{l}\text { Respo- } \\
\text { ndents' } \\
\text { age }\end{array}$} & $31-40$ & 44 & 46.8 & 49.4 & 80.9 \\
\hline & $41-50$ & 17 & 18.1 & 19.1 & 100 \\
\hline & Total & 89 & 94.7 & 100 & \\
\hline \multirow{2}{*}{$\begin{array}{l}\text { Missing } \\
\text { Total }\end{array}$} & System & 5 & $5 \cdot 3$ & & \\
\hline & & 94 & 100 & & \\
\hline \multirow{6}{*}{$\begin{array}{l}\text { Work } \\
\text { experience }\end{array}$} & $1-5$ & 20 & 21.3 & 24.7 & 24.7 \\
\hline & $6-11$ & 30 & 31.9 & 37.0 & 61.7 \\
\hline & $12-17$ & 21 & 22.3 & 25.9 & 87.7 \\
\hline & $18-23$ & 8 & 8.5 & 9.9 & 97.5 \\
\hline & $24-29$ & 2 & 2.1 & 2.5 & 100.0 \\
\hline & Total & 81 & 86.2 & 100.0 & \\
\hline \multirow{3}{*}{$\begin{array}{l}\text { Missing } \\
\text { Total }\end{array}$} & System & 13 & 13.8 & & \\
\hline & & 94 & 100.0 & & \\
\hline & OND/NCE & 16 & 17 & 17.4 & 17.4 \\
\hline \multirow{3}{*}{$\begin{array}{l}\text { Educational } \\
\text { qualification }\end{array}$} & HND/B.Sc. & 64 & 68.1 & 69.6 & 87 \\
\hline & MBA/M.Sc. & 12 & 12.8 & 13 & 100 \\
\hline & Total & 92 & 97.9 & 100 & \\
\hline \multirow{2}{*}{$\begin{array}{r}\text { Missing } \\
\text { Tota }\end{array}$} & System & 2 & 2.1 & & \\
\hline & & 94 & 100 & & \\
\hline
\end{tabular}

Source: Field Survey, 2018

The majority of the respondents $(78.7 \%)$ have at least either an HND certificate or the First Degree. The education and experience variables show the reliability of the information supplied for the purpose of conducting this research study. As can be seen in Table 1, about $78.3 \%$ have at least 12 years of work experience in their respective banks.
Conditions for Granting SMEs a Loan and the Nature of Business - Table 2 shows a comparison between the track record expected from SMEs and the work experience of the financial institutions' staff. At least $86.4 \%(70 / 81)$ of the respondents have agreed $(29.6 \%) /$ strongly agreed (56.8\%) that SMEs with a good record of performance as viewed by the respondents will be able to access loans. As can be seen in Table 2, there is an about $66.7 \%$ perpendicular agreement for "strongly agreed" and 12-17 work experience among the banks' staff. It is also evidenced in Table 2 that about $93.8 \%$ of the respondents have agreed (50.6\%)/strongly agreed $(43.2 \%)$ that a good business understanding by the owners of SMEs forms the basis for granting a loan to them, whereas $79.8 \%$ have agreed $(50.6 \%) /$ strongly agreed $(29.6 \%)$ that the SMEs with the ability to demonstrate a good feasibility study for the survival of a new business startup will attract bank lending at an affordable rate.

Table 3 reveals that technological businesses are more likely to have access to bank loans (41.1\% "strongly agreed") than manufacturing businesses (33.7\%), agrobusinesses (farming) (31.5\%), construction/building businesses (33\%), and servicing businesses (26.1\%). Also, banks have agreed to finance agro-businesses (farming) (50\%) much more than manufacturing businesses (38.2\%), processing businesses (15.4\%), technology-related businesses $(40 \%)$, construction / building-related businesses (37.4\%) and servicerelated businesses. The table also reveals that many of the respondents are well-educated, which is reflected in their responses.

Procedures for testing the hypotheses - Having considered the extent to which the respondents have agreed with the type of the business to be financed, it is not clear which of the businesses is the most attractive for financing because of a different rating. Hence the need to carry out a further testing so as to ascertain which of these businesses is the most attractive for bank lending. The hypotheses for this study are tested below with the aid of the relevant statistics.

In the model summary (Table 4), Model 1 represents the entry of the age of the business that accounts for only $13.8 \%$ of the variance of the SMEs' access to a loan $\left(R^{2}=0.138, F=13.239, p<0.000\right)$. The inclusion 
Table 2 Work experience by conditions for granting loans to SMEs

\begin{tabular}{|c|c|c|c|c|c|c|c|}
\hline & \multicolumn{5}{|c|}{ Work Experience } & \multirow[t]{2}{*}{ Total } \\
\hline & & $1-5$ & $6-11$ & $12-17$ & $18-23$ & $24-29$ & \\
\hline \multirow{5}{*}{$\begin{array}{l}\text { Track records } \\
\text { for good } \\
\text { performance }\end{array}$} & $\begin{array}{l}\text { Strongly } \\
\text { Disagreed }\end{array}$ & $1(5.00 \%)$ & $0(0.00 \%)$ & $1(4.80 \%)$ & $0(0.00 \%)$ & $0(0.00 \%)$ & $2(2.50 \%)$ \\
\hline & Disagreed & $1(5.00 \%)$ & $0(0.00 \%)$ & $0(0.00 \%)$ & $0(0.00 \%)$ & $0(0.00 \%)$ & $1(1.20 \%)$ \\
\hline & Neutral & $1(5.00 \%)$ & $3(10.00 \%)$ & $1(4.80 \%)$ & $2(25.00 \%)$ & $1(50.00 \%)$ & $8(9.90 \%)$ \\
\hline & Agreed & $6(30.00 \%)$ & $10(33.30 \%)$ & $5(23.80 \%)$ & $3(37.50 \%)$ & $0(0.00 \%)$ & $24(29.60 \%)$ \\
\hline & $\begin{array}{l}\text { Strongly } \\
\text { Agreed }\end{array}$ & $11(55.00 \%)$ & $17(56.70 \%)$ & $14(66.70 \%)$ & $3(37.50 \%)$ & $1(50.00 \%)$ & $46(56.80 \%)$ \\
\hline Total & & $20(100.00 \%)$ & $30(100.00 \%)$ & $21(100.00 \%)$ & $8(100.00 \%)$ & $2(100.00 \%)$ & $81(100.00 \%)$ \\
\hline \multirow{4}{*}{$\begin{array}{l}\text { Business } \\
\text { understanding }\end{array}$} & Disagreed & $1(5.00 \%)$ & $0(0.00 \%)$ & $1(4.80 \%)$ & $0(0.00 \%)$ & $0(0.00 \%)$ & $2(2.50 \%)$ \\
\hline & Neutral & $1(5.00 \%)$ & $0(0.00 \%)$ & $2(9.50 \%)$ & $0(0.00 \%)$ & $0(0.00 \%)$ & $3(3.70 \%)$ \\
\hline & Agreed & $12(60.00 \%)$ & $16(53.30 \%)$ & $8(38.10 \%)$ & $5(62.50 \%)$ & $0(0.00 \%)$ & $41(50.60 \%)$ \\
\hline & $\begin{array}{l}\text { Strongly } \\
\text { Agreed }\end{array}$ & $6(30.00 \%)$ & $14(46.70 \%)$ & $10(47.60 \%)$ & $3(37.50 \%)$ & $2(100.00 \%)$ & $35(43.20 \%)$ \\
\hline Total & & $20(100.00 \%)$ & $30(100.00 \%)$ & $21(100.00 \%)$ & $8(100.00 \%)$ & $2(100.00 \%)$ & $81(100.00 \%)$ \\
\hline \multirow{4}{*}{$\begin{array}{l}\text { Good } \\
\text { feasibility } \\
\text { study for } \\
\text { survival }\end{array}$} & Disagreed & $0(0.00 \%)$ & $0(0.00 \%)$ & $1(4.80 \%)$ & $0(0.00 \%)$ & $0(0.00 \%)$ & $1(1.20 \%)$ \\
\hline & Neutral & $4(20.00 \%)$ & $5(16.70 \%)$ & $5(23.80 \%)$ & $1(12.50 \%)$ & $0(0.00 \%)$ & $15(18.50 \%)$ \\
\hline & Agreed & $9(45.00 \%)$ & $17(56.70 \%)$ & $10(47.60 \%)$ & $3(37.50 \%)$ & $2(100.00 \%)$ & $41(50.60 \%)$ \\
\hline & $\begin{array}{l}\text { Strongly } \\
\text { Agreed }\end{array}$ & $7(35.00 \%)$ & $8(26.70 \%)$ & $5(23.80 \%)$ & $4(50.00 \%)$ & $0(0.00 \%)$ & $24(29.60 \%)$ \\
\hline Total & & $20(100.00 \%)$ & $30(100.00 \%)$ & $21(100.00 \%)$ & $8(100.00 \%)$ & $2(100.00 \%)$ & $81(100.00 \%)$ \\
\hline \multirow{4}{*}{$\begin{array}{l}\text { Good internal } \\
\text { control }\end{array}$} & Disagreed & $0(0.00 \%)$ & $1(3.30 \%)$ & $1(4.80 \%)$ & $0(0.00 \%)$ & $0(0.00 \%)$ & $2(2.50 \%)$ \\
\hline & Neutral & $3(15.00 \%)$ & $2(6.70 \%)$ & $3(14.30 \%)$ & $1(12.50 \%)$ & $0(0.00 \%)$ & $9(11.10 \%)$ \\
\hline & Agreed & $9(45.00 \%)$ & $11(36.70 \%)$ & $5(23.80 \%)$ & $1(12.50 \%)$ & $1(50.00 \%)$ & $27(33.30 \%)$ \\
\hline & $\begin{array}{l}\text { Strongly } \\
\text { Agreed }\end{array}$ & $8(40.00 \%)$ & $16(53.30 \%)$ & $12(57.10 \%)$ & $6(75.00 \%)$ & $1(50.00 \%)$ & $43(53.10 \%)$ \\
\hline Total & & $20(100.00 \%)$ & $30(100.00 \%)$ & $21(100.00 \%)$ & $8(100.00 \%)$ & $2(100.00 \%)$ & $81(100.00 \%)$ \\
\hline \multirow{4}{*}{$\begin{array}{l}\text { Good financial } \\
\text { record }\end{array}$} & Disagreed & $1(5.00 \%)$ & $1(3.30 \%)$ & $0(0.00 \%)$ & $1(12.50 \%)$ & $0(0.00 \%)$ & $3(3.70 \%)$ \\
\hline & Neutral & $1(5.00 \%)$ & $4(13.30 \%)$ & $1(4.80 \%)$ & $0(0.00 \%)$ & $0(0.00 \%)$ & $6(7.40 \%)$ \\
\hline & Agreed & $13(65.00 \%)$ & $16(53.30 \%)$ & $10(47.60 \%)$ & $5(62.50 \%)$ & $0(0.00 \%)$ & $44(54.30 \%)$ \\
\hline & $\begin{array}{l}\text { Strongly } \\
\text { Agreed }\end{array}$ & $5(25.00 \%)$ & $9(30.00 \%)$ & $10(47.60 \%)$ & $2(25.00 \%)$ & $2(100.00 \%)$ & $28(34.60 \%)$ \\
\hline Total & & $20(100.00 \%)$ & $30(100.00 \%)$ & $21(100.00 \%)$ & $8(100.00 \%)$ & $2(100.00 \%)$ & $81(100.00 \%)$ \\
\hline
\end{tabular}

Source: Field Survey, 2018

of the financial ratio variable (Model 2) increases the explained variance from $13.8 \%$ to $21.5 \%$, and is significant $\left(R^{2}=0.215 ; F=8.099, p<0.006\right)$. Similarly, the entry of the SMEs' internal control system (Model 3) brings the total explained variables from $21.5 \%$ to
$28.7 \%$, and is also significant $\left(\mathrm{R}^{2}=0.287 ; \mathrm{F}=8.207, \mathrm{p}<\right.$ 0.005). The results output in Table $4 \mathrm{a}$ imply that the age of a business, the financial ratio, and the internal control system explained about $28.7 \%$ of the condition for granting a loan to SMEs. 
Table 3 Respondents' education by SMEs financing

\begin{tabular}{|c|c|c|c|c|c|}
\hline & & \multicolumn{3}{|c|}{ Educational Qualification } & \multirow{2}{*}{ Total } \\
\hline & & OND/NCE & HND/B.SC. & MBA/M.SC. & \\
\hline \multirow{4}{*}{$\begin{array}{l}\text { Manufacturing } \\
\text { Companies }\end{array}$} & Strongly Disagreed & $2(13.30 \%)$ & $0(0.00 \%)$ & $0(0.00 \%)$ & $2(2.20 \%)$ \\
\hline & Disagreed & $0(0.00 \%)$ & $2(3.20 \%)$ & $1(8.30 \%)$ & $3(3.40 \%)$ \\
\hline & Neutral & $3(20.00 \%)$ & $13(21.00 \%)$ & $4(33.30 \%)$ & $20(22.50 \%)$ \\
\hline & Agreed & $3(20.00 \%)$ & $28(45.20 \%)$ & $3(25.00 \%)$ & $34(38.20 \%)$ \\
\hline \multicolumn{2}{|l|}{ Total } & $15(100.00 \%)$ & $62(100.00 \%)$ & $12(100.00 \%)$ & $89(100.00 \%)$ \\
\hline \multirow{5}{*}{$\begin{array}{l}\text { Processing } \\
\text { Businesses }\end{array}$} & Strongly Disagreed & $0(0.00 \%)$ & $1(1.60 \%)$ & $0(0.00 \%)$ & $1(1.10 \%)$ \\
\hline & Disagreed & $0(0.00 \%)$ & $4(6.30 \%)$ & $0(0.00 \%)$ & $4(4.40 \%)$ \\
\hline & Neutral & $4(25.00 \%)$ & $10(15.90 \%)$ & $0(0.00 \%)$ & $14(15.40 \%)$ \\
\hline & Agreed & $8(0.00 \%)$ & $28(44.40 \%)$ & $3(25.00 \%)$ & $39(42.90 \%)$ \\
\hline & Strongly Agreed & $4(25.00 \%)$ & $20(31.70 \%)$ & $9(75.0 \%)$ & $33(36.30 \%)$ \\
\hline \multicolumn{2}{|l|}{ Total } & $16(100.00 \%)$ & $63(100.00 \%)$ & $12(100.00 \%)$ & $91(100.00 \%)$ \\
\hline \multirow{4}{*}{ Technology } & Disagreed & $2(12.50 \%)$ & $3(4.80 \%)$ & $0(0.00 \%)$ & $5(5.60 \%)$ \\
\hline & Neutral & $2(12.50 \%)$ & $8(12.70 \%)$ & $2(18.20 \%)$ & $12(13.30 \%)$ \\
\hline & Agreed & $4(25.00 \%)$ & $30(47.60 \%)$ & $2(18.20 \%)$ & $36(40.00 \%)$ \\
\hline & Strongly Agreed & $8(50.00 \%)$ & $22(34.90 \%)$ & $7(63.60 \%)$ & $37(41.10 \%)$ \\
\hline \multicolumn{2}{|l|}{ Total } & $16(100.00 \%)$ & $63(100.00 \%)$ & $11(100.00 \%)$ & $90(100.00 \%)$ \\
\hline \multirow{4}{*}{$\begin{array}{l}\text { Agro-business } \\
\text { (farming) }\end{array}$} & Disagreed & $1(6.30 \%)$ & $3(4.70 \%)$ & $0(0.00 \%)$ & $4(4.30 \%)$ \\
\hline & Neutral & $3(18.80 \%)$ & $9(14.10 \%)$ & $1(8.30 \%)$ & $13(14.10 \%)$ \\
\hline & Agreed & $6(37.50 \%)$ & $33(51.60 \%)$ & $7(58.30 \%)$ & $46(50.00 \%)$ \\
\hline & Strongly Agreed & $6(37.50 \%)$ & $19(29.70 \%)$ & $4(33.30 \%)$ & $29(31.50 \%)$ \\
\hline \multicolumn{2}{|l|}{ Total } & $16(100.00 \%)$ & $64(100.00 \%)$ & $12(100.00 \%)$ & $92(100.00 \%)$ \\
\hline \multirow{4}{*}{$\begin{array}{l}\text { Construction/ } \\
\text { Building }\end{array}$} & Disagreed & $1(6.30 \%)$ & $2(3.20 \%)$ & $0(0.00 \%)$ & $3(3.30 \%)$ \\
\hline & Neutral & $4(25.0 \%)$ & $19(30.2 \%)$ & $1(8.30 \%)$ & $24(26.40 \%)$ \\
\hline & Agreed & $6(37.50 \%)$ & $21(33.30 \%)$ & $7(58.3 \%)$ & $34(37.4 \%)$ \\
\hline & Strongly Agreed & $5(31.30 \%)$ & $21(33.30 \%)$ & $4(33.30 \%)$ & $29(33 \%)$ \\
\hline \multirow[t]{3}{*}{ Total } & & $16(100.00 \%)$ & $63(100.00 \%)$ & $12(100.00 \%)$ & $91(100.00 \%)$ \\
\hline & Strongly Disagreed & $2(12.50 \%)$ & $0(0.00 \%)$ & $1(.8 .3 \%)$ & $3(3.3 \%)$ \\
\hline & Disagreed & $0(0.00 \%)$ & $3(4.70 \%)$ & $0(0.00 \%)$ & $3(3.3 \%)$ \\
\hline \multirow[t]{3}{*}{ Service } & Neutral & $5(31.30 \%)$ & 22 & $0(0.00 \%)$ & $27(29.3 \%)$ \\
\hline & Agreed & $6(37.50 \%)$ & $23(35.90 \%)$ & $6(50.00 \%)$ & $35(38.0 \%)$ \\
\hline & Strongly Agreed & $3(18.80 \%)$ & $16(25.00 \%)$ & $5(41.70 \%)$ & $24(26.10 \%)$ \\
\hline Total & & 16 (100.00\%) & 64 (100.00\%) & $12(100.00 \%)$ & $92(100.00 \%)$ \\
\hline
\end{tabular}

Source: Field Survey, 2018

Table $4 \mathrm{~b}$ shows a direct impact of the independent variables on the requirement for granting loans to SMEs. Based on the data provided in the table, while it is evident that the age of a business $\left(\lambda_{1}=0.146, t=\right.$ $1.637, p>0.05)$ has no significant influence on SMEs' access to a loan, the financial ratio $\left(\lambda_{2}=0.226, t=2.779\right.$, $p<0.007)$ and the internal control system $\left(\lambda_{3}=0.311\right.$, $t=2.865, p<0.005$ ) have a significant influence on SMEs' access to bank lending. Based on the findings accounted for in Tables $4 a-b$, it can be concluded that 
the age of a business is not supported, whereas the financial ratio and the internal control system are supported. Consequently, it can be concluded that a good financial ratio and the internal control system have a significant impact on the conditions for loan access, whereas the age of a business has nothing to do with the condition for accessing loans from financial institutions.
Table 5a shows how SMEs' good working capital and liquidity ratio are related to bank lending. In the table, good working capital (Model 2) explains $66.2 \%$ of a part of the criteria for SMEs' financial ratio by the F Change $\left(R^{2}=0.662 ; F=168.719, p<0.000\right)$. Also, the entry of SMEs' liquidity (Model 2) results in an R square change of 0.283 , which means that the variable of asset liquidity contributes $28.3 \%$, which

Table 4a The model summary of SMEs' years in business, financial ratio and internal control system related to access to bank lending

\begin{tabular}{c|ccccccccc}
\hline \multirow{2}{*}{ Model } & $\mathrm{R}$ & R Square & $\begin{array}{c}\text { Adjusted } \\
\text { R Square }\end{array}$ & $\begin{array}{c}\text { Std. Error } \\
\text { of the } \\
\text { Estimate }\end{array}$ & $\begin{array}{c}\text { R Square } \\
\text { Change }\end{array}$ & F Change & df1 & df2 & $\begin{array}{c}\text { Sig. F } \\
\text { Change }\end{array}$ \\
\hline 1 & $.371^{\mathrm{a}}$ & 0.138 & 0.127 & 0.52421 & 0.138 & 13.239 & 1 & 83 & 0.000 \\
2 & $.464^{\mathrm{b}}$ & 0.215 & 0.196 & 0.50313 & 0.078 & 8.099 & 1 & 82 & 0.006 \\
3 & $.536^{\mathrm{c}}$ & 0.287 & 0.261 & 0.48238 & 0.072 & 8.207 & 1 & 81 & 0.005 \\
\hline
\end{tabular}

a. Predictors: (Constant), Age of Business

b. Predictors: (Constant), Age of Business, Financial Ratio

c. Predictors: (Constant), Age of Business, Financial Ratio, Internal Control System

Source: Author

Table $4 \mathrm{~b}$ The impact of the SMEs' years in business, financial ratio and internal control system on their access to bank lending

\begin{tabular}{|c|c|c|c|c|c|c|c|c|}
\hline & \multirow{2}{*}{ Model } & \multicolumn{2}{|c|}{$\begin{array}{c}\text { Unstandardized } \\
\text { Coefficients }\end{array}$} & \multirow{2}{*}{$\begin{array}{c}\text { Standardized } \\
\text { Coefficients } \\
\text { Beta }\end{array}$} & \multirow[t]{2}{*}{$\mathrm{T}$} & \multirow{2}{*}{ Sig. } & \multicolumn{2}{|c|}{$\begin{array}{l}95.0 \% \text { Confidence } \\
\text { Interval for B }\end{array}$} \\
\hline & & B & Std. Error & & & & $\begin{array}{l}\text { Lower } \\
\text { Bound }\end{array}$ & $\begin{array}{l}\text { upper } \\
\text { Bound }\end{array}$ \\
\hline \multirow{3}{*}{1} & (Constant) & 2.838 & 0.365 & & 7.784 & 0.000 & 2.113 & 3.564 \\
\hline & Age of Business & 0.314 & 0.086 & 0.371 & 3.639 & 0.000 & 0.142 & 0.485 \\
\hline & (Constant) & 2.121 & 0.431 & & 4.916 & 0.000 & 1.263 & 2.979 \\
\hline \multirow[t]{3}{*}{2} & Age of Business & 0.245 & 0.086 & 0.29 & 2.85 & 0.006 & 0.074 & 0.417 \\
\hline & Financial Ratio & 0.241 & 0.085 & 0.29 & 2.846 & 0.006 & 0.072 & 0.409 \\
\hline & (Constant) & 1.247 & 0.514 & & 2.427 & 0.017 & 0.225 & 2.27 \\
\hline \multirow{3}{*}{3} & Age of Business & 0.146 & 0.089 & 0.173 & 1.637 & 0.106 & -0.032 & 0.325 \\
\hline & Financial Ratio & 0.226 & 0.081 & 0.272 & 2.779 & 0.007 & 0.064 & 0.387 \\
\hline & Internal Control System & 0.311 & 0.109 & 0.296 & 2.865 & 0.005 & 0.095 & 0.527 \\
\hline
\end{tabular}

Dependent Variable: Condition for Granting Loans to SMEs. 
significantly brings the total explained variables from $66.2 \%$ to $94.5 \%\left(R^{2}=0.945 ; F=8.207, p<0.005\right)$.

Table $5 b$ contains the regression results of good working capital and the liquidity ratio. Good working capital and the ease of the liquidity of the asset explains $94.5 \%$ of the reasons why financial institutions extend a credit to SMEs. According to the findings accounted for in the table, good working capital $\left(\lambda_{1}=0.365, t=\right.$ 12.717, $p<0.0000)$ and the liquidity of an asset $\left(\lambda_{2}=\right.$ $0.553, t=20.972, p<0.000$ ) have a significant influence on the SMEs' financial ratio that financial institutions consider when financing SMEs in Jos Metropolis. Hence, the hypothesis is supported. Based on these results, a conclusion can be drawn that good working capital and the liquidity of an asset significantly influence SMEs' financial ratio, which can be used as one of the criteria of financial institutions when granting loans to SMEs.

The relationship between the financial ratio and SMEs financing is significant according to the $\mathrm{F}$ Change test $\left(R^{2}=0.118, F=10.844, p<0.001\right)$. The introduction of educational/vocational training (Model 2) results in an $\mathrm{R}$ square change of 0.071 , which means that education and vocational training contributes $7.1 \%$ and brings the total explained variables from $11.8 \%$ to $19 \%\left(R^{2}=0.19 ; \mathrm{F}=7.055, \mathrm{p}<0.001\right)$. The extent to which the SMEs' owners' financial ratio and educational/ vocational training are related to SMEs financing is only explained by $19 \%$.

Table 6b shows the impact of SMEs' financial ratio and the entrepreneur's educational/vocational training on

Table 5a The model summary of how SMEs' good working capital and liquidity ratio are related to bank lending

\begin{tabular}{c|ccccccccc}
\hline \multirow{2}{*}{ Model } & $\mathrm{R}$ & $\begin{array}{c}\mathrm{R} \\
\text { Square }\end{array}$ & $\begin{array}{c}\text { Adjusted } \\
\mathrm{R} \text { Square }\end{array}$ & $\begin{array}{c}\text { Std. Error of } \\
\text { the Estimate }\end{array}$ & $\begin{array}{c}\text { R Square } \\
\text { Change }\end{array}$ & F Change & df1 & df2 & Sig. F Change \\
\hline 1 & $.814^{\mathrm{a}}$ & 0.662 & 0.658 & 0.39517 & 0.662 & 168.719 & 1 & 86 & 0.000 \\
2 & $.972^{\mathrm{b}}$ & 0.945 & 0.944 & 0.15996 & 0.283 & 439.836 & 1 & 85 & 0.000 \\
\hline
\end{tabular}

a. Predictors: (Constant), Good working capital

b. Predictors: (Constant), Good working capital, Liquidity of asset.

Source: Author

Table $5 \mathbf{b}$ The impact of SMEs' good working capital and liquidity ratio on bank lending

\begin{tabular}{|c|c|c|c|c|c|c|c|c|}
\hline & \multirow{2}{*}{ Model } & \multicolumn{2}{|c|}{$\begin{array}{l}\text { Unstandardized } \\
\text { Coefficients }\end{array}$} & \multirow[t]{2}{*}{$\begin{array}{l}\text { Standardized } \\
\text { Coefficients }\end{array}$} & \multirow{2}{*}{$\mathrm{T}$} & \multirow{2}{*}{ Sig. } & \multicolumn{2}{|c|}{$\begin{array}{l}\text { 95.0\% Confidence } \\
\text { Interval for B }\end{array}$} \\
\hline & & & $\begin{array}{l}\text { Std. } \\
\text { Error }\end{array}$ & & & & $\begin{array}{l}\text { Lower } \\
\text { Bound }\end{array}$ & $\begin{array}{l}\text { Upper } \\
\text { Bound }\end{array}$ \\
\hline \multirow{2}{*}{1} & (Constant) & 1.171 & 0.234 & & 5.003 & 0.000 & 0.706 & 1.637 \\
\hline & Good working capital & 0.731 & 0.056 & 0.814 & 12.989 & 0.000 & 0.619 & 0.843 \\
\hline \multirow{3}{*}{2} & (Constant) & 0.364 & 0.102 & & 3.557 & 0.001 & 0.16 & 0.567 \\
\hline & Good working capital & 0.365 & 0.029 & 0.406 & 12.717 & 0.000 & 0.308 & 0.422 \\
\hline & Liquidity of asset & 0.553 & 0.026 & 0.67 & 20.972 & 0.000 & 0.5 & 0.605 \\
\hline
\end{tabular}

Dependent Variable: Financial Ratio 
the business undertaken. The results show that the financial ratio $\left(\lambda_{1}=0.466, t=3.198, p<0.001\right)$ and $\mathrm{Edu} /$ Voc. training $\left(\lambda_{2}=0.454, t=2.656, p<0.01\right)$ jointly have a positive and significant impact on SMEs financing. The hypothesis is also supported, which means that banks will have to consider SMEs' financial ratio, as well as the educational/vocational training of SMEs' operators, before extending a credit to them for running their business.

Table 7 also contains the interrelationships between the financial ratio, a short-term credit collection, good working capital and the liquidity ratio. The results show that the financial ratio has a very strong and significant relationship with a short-term credit collection $(\mathrm{r}=.881, \mathrm{p}<0.05)$, good working capital ( $\mathrm{r}$ $=.8140, \mathrm{p}<0.05)$ and the liquidity of the asset $(\mathrm{r}=0.917$, $\mathrm{p}<0.05)$. Similarly, a short-term credit collection has a significant relationship with good working capital $(0.530, p<0.05)$ and the liquidity of an asset $(0.774$, $\mathrm{p}<0.05)$. In addition, good working capital and the liquidity of an asset both demonstrate a significant relationship with each other $(r=0.608, p<0.05)$. Hence, the hypothesis is upheld and a conclusion can be drawn that there is a strong and significant interrelationship between the financial ratio, a shortterm collection period, good working capital and the liquidity of assets that a financial institution

Table 6a The model summary of the relationship between the financial ratio and Educational/Vocational training, and SMEs financing

\begin{tabular}{c|ccccccccc}
\hline Model & R & R Square & $\begin{array}{c}\text { Adjusted } \\
\text { R Square }\end{array}$ & $\begin{array}{c}\text { Std. Error of } \\
\text { the Estimate }\end{array}$ & $\begin{array}{c}\text { R Square } \\
\text { Change }\end{array}$ & F Change & df1 & df2 & Sig. F Change \\
\hline 1 & $.344^{\mathrm{a}}$ & 0.118 & 0.107 & 0.93491 & 0.118 & 10.844 & 1 & 81 & 0.001 \\
2 & $.435^{\mathrm{b}}$ & 0.19 & 0.169 & 0.90181 & 0.071 & 7.055 & 1 & 80 & 0.01 \\
\hline
\end{tabular}

a. Predictors: (Constant), Financial Ratio

b. Predictors: (Constant), Financial Ratio, Educational / Vocational Training

Source: Author

Table $6 \mathbf{b}$ The impact of the financial ratio and Educational/Vocational training on SMEs financing

\begin{tabular}{|c|c|c|c|c|c|c|c|c|}
\hline & \multirow{2}{*}{ Model } & \multicolumn{2}{|c|}{$\begin{array}{l}\text { Unstandardized } \\
\text { Coefficients }\end{array}$} & \multirow{2}{*}{$\begin{array}{c}\text { Standardized } \\
\text { Coefficients } \\
\text { Beta }\end{array}$} & \multirow{2}{*}{$\mathrm{T}$} & \multirow{2}{*}{ Sig. } & \multicolumn{2}{|c|}{$\begin{array}{l}95.0 \% \text { Confidence } \\
\text { Interval for B }\end{array}$} \\
\hline & & B & Std. Error & & & & $\begin{array}{l}\text { Lower } \\
\text { Bound }\end{array}$ & $\begin{array}{l}\text { Upper } \\
\text { Bound }\end{array}$ \\
\hline \multirow{2}{*}{1} & (Constant) & 2.099 & 0.637 & & 3.292 & 0.001 & 0.83 & 3.367 \\
\hline & Financial Ratio & 0.496 & 0.151 & 0.344 & 3.293 & 0.001 & 0.196 & 0.796 \\
\hline \multirow{3}{*}{2} & (Constant) & 0.285 & 0.919 & & 0.31 & 0.757 & -1.543 & 2.114 \\
\hline & Financial Ratio & 0.466 & 0.146 & 0.323 & 3.198 & 0.002 & 0.176 & 0.756 \\
\hline & $\begin{array}{l}\text { Edu / Voc. } \\
\text { Training }\end{array}$ & 0.454 & 0.171 & 0.268 & 2.656 & 0.01 & 0.114 & 0.794 \\
\hline
\end{tabular}

a. Dependent Variable: SMEs Financing 
uses in order to make an assessment of SMEs' credit worthiness.

The variability of SMEs' access to a bank loan among financial institutions - Table 8a reveals a meanstandard test of financial institutions' conditions for granting loans to SMEs in Jos Metropolis. The scale of the measurement ranges from 1 to 5 . Amongst the conditions listed for granting a loan to SMEs, the SME's ability to monitor how a loan is used, SMEs' operators' ability to account for the judicious use of a loan and the government as a guarantor are also included as the key conditions, in which the overall averages for individual banks are reported in Table 8a. The means in the table reveal that the largest number of the banks are more likely to agree upon these conditions.

Also, assessing individual financial institutions by applying the level of the mean/standard of a number

Table 7 The interrelationship between SMEs' financial ratios

\begin{tabular}{l|cccc}
\hline Pearson Correlation & Financial ratio & $\begin{array}{c}\text { Short collection } \\
\text { period }\end{array}$ & $\begin{array}{c}\text { Good working } \\
\text { capital }\end{array}$ & $\begin{array}{c}\text { Liquidity of the } \\
\text { asset }\end{array}$ \\
\hline Financial Ratio & 1 & & & \\
Short-term credit & $.881^{*}$ & 1 & & \\
collection period & $.814^{*}$ & $.530^{*}$ & 1 & 1 \\
Good working capital & $.917^{*}$ & $.774^{*}$ & $.608^{*}$ & \\
Liquidity of the asset & \multicolumn{2}{c}{} \\
\hline
\end{tabular}

Source: Author

Table 8a The condition for granting loans to SME Businesses by financial institutions in Jos Metropolis

\begin{tabular}{|c|c|c|c|c|c|c|c|c|}
\hline \multirow{2}{*}{ Financial institutions } & \multirow{2}{*}{$\mathrm{N}$} & \multirow{2}{*}{ Mean } & \multirow{2}{*}{$\begin{array}{c}\text { Std. } \\
\text { Deviation }\end{array}$} & \multirow{2}{*}{$\begin{array}{l}\text { Std. } \\
\text { Error }\end{array}$} & \multicolumn{2}{|c|}{$\begin{array}{l}95 \% \text { Confidence } \\
\text { Interval for Mean }\end{array}$} & \multirow{2}{*}{ Minimum } & \multirow{2}{*}{ Maximum } \\
\hline & & & & & $\begin{array}{l}\text { Lower } \\
\text { Bound }\end{array}$ & $\begin{array}{l}\text { Upper } \\
\text { Bound }\end{array}$ & & \\
\hline Access Bank & 11 & 4.2879 & .24823 & .07484 & 4.1211 & 4.4546 & 3.83 & 4.83 \\
\hline Bowans Microfinance & 5 & 4.2000 & .29814 & .13333 & 3.8298 & 4.5702 & 3.83 & 4.50 \\
\hline Diamond Bank & 5 & 3.3000 & 1.06979 & .47842 & 1.9717 & 4.6283 & 2.33 & 4.67 \\
\hline Ecobank & 11 & 4.3333 & .27889 & .08409 & 4.1460 & 4.5207 & 4.00 & 4.83 \\
\hline FCMB Bank & 6 & 4.2500 & .17480 & .07136 & 4.0666 & 4.4334 & 4.00 & 4.50 \\
\hline First Bank & 7 & 3.6667 & .31914 & .12062 & 3.3715 & 3.9618 & 3.17 & 4.00 \\
\hline IBTC Bank & 8 & 4.2917 & .44320 & .15670 & 3.9211 & 4.6622 & 3.50 & 4.83 \\
\hline Light Cooperative Microfinance & 1 & 3.5000 & . & . & . & . & 3.50 & 3.50 \\
\hline Sky Bank & 1 & 4.1667 & . & . & . & . & 4.17 & 4.17 \\
\hline UBA & 2 & 4.5000 & .70711 & .50000 & -1.8531 & 10.8531 & 4.00 & 5.00 \\
\hline Union Bank & 6 & 4.2500 & .64765 & .26440 & 3.5703 & 4.9297 & 3.33 & 5.00 \\
\hline Unity Bank & 7 & 4.2619 & .50787 & 19196 & 3.7922 & 4.7316 & 3.50 & 4.83 \\
\hline Zenith Bank & 6 & 3.8056 & .66179 & .27017 & 3.1111 & 4.5001 & 2.83 & 4.50 \\
\hline Light Microfinance & 8 & 4.3958 & .62955 & .22258 & 3.8695 & 4.9221 & 3.00 & 5.00 \\
\hline Bank of Agriculture & 3 & 4.2222 & .67358 & .38889 & 2.5490 & 5.8955 & 3.50 & 4.83 \\
\hline Total & 87 & 4.1437 & .55578 & .05959 & 4.0252 & 4.2621 & 2.33 & 5.00 \\
\hline
\end{tabular}


of the respondents reveals that Access Bank $\left(n_{A}=11\right.$, $\left.A_{\bar{X}}=4.2879, \sigma_{A}=0.24823\right)$ is very much stable with respect to these conditions when granting a loan, more than Eco Bank $\left(n_{E}=11, E_{\bar{X}}=4.3333, \sigma_{E}=0.2788\right)$ (Table 8a) Similarly, the FCMB $\left(n_{F}=6, F_{\bar{X}}=4.25, \sigma_{F}=\right.$ $0.1748)$ is more likely to grant a loan to SMEs than the $\operatorname{IBTC}\left(n_{I}=8, I_{\bar{X}}=4.2917, \sigma_{I}=0.4432\right)$.

The other financial institutions' mean standards are as shown in the table. Diamond Bank $\left(n_{D}=5, D_{\bar{X}}=3.3333\right.$, $\sigma_{D}=1.06979$ ), however is very likely to be instable with respect to the conditions for extending loans to SME businesses in Jos Metropolis. Figure 1 also reveals the degree at which financial institutions are involved and the variability with the mean conditions listed. Hence, Table $8 \mathrm{~b}$ allows us to conclude that access to bank loans by SMEs businesses significantly varies from one financial institution to another $(F=2.249$, $D f[14,72], p<0.013)$. The extent of the variability of the financial institutions' conditions for granting loans to SMEs is shown in Figure 1.

Table $8 \mathrm{~b}$ The condition for granting loans to SMEs

\begin{tabular}{l|ccccc}
\hline & $\begin{array}{c}\text { Sum of } \\
\text { Squares }\end{array}$ & Df & $\begin{array}{c}\text { Mean } \\
\text { Square }\end{array}$ & F & Sig. \\
\hline $\begin{array}{l}\text { Between } \\
\text { Groups }\end{array}$ & 8.083 & 14 & .577 & 2.249 & .013 \\
Within & 18.483 & 72 & .257 & & \\
Groups & & & & & \\
Total & 26.565 & 86 & & & \\
\hline
\end{tabular}

Source: Author

\section{CONCLUSION}

When seeking a loan from a bank, SMEs' operators/ owners in Nigeria are faced with one of the major challenges. Financial institutions impose the criteria such SMEs need to meet before such financial institutions extend loans to them; most frequently, however, the SMEs in question are not aware of those criteria. This research study has examined these

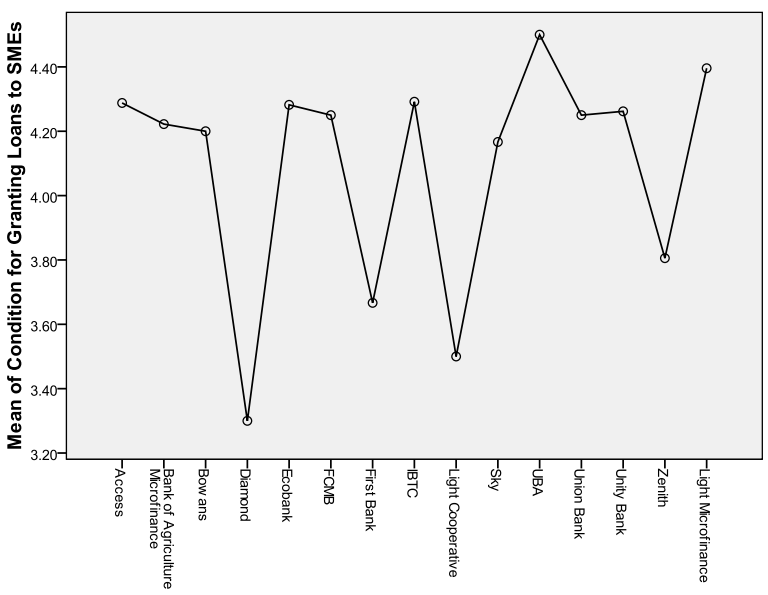

Figure 1 Financial institutions

Source: Author

criteria and mechanisms applied by the selected financial institutions in Jos Metropolis. Some of the major findings account for the fact that the age of a business, a good financial ratio and the internal control system, such as well-kept financial records or another book-keeping of business activities, significantly influence financial institutions' decisionmaking mechanisms when granting loans to SMEs. These results show that financial institutions are more likely to grant loans to older SME businesses with a good financial ratio and a good internal control system.

Similarly, good working capital and asset liquidity are found to significantly influence SMEs financing. This suggests that, as SMEs' working capital and the ease of the asset conversion into cash increase, there is a greater chance for SMEs to access credit facilities extended by financial institutions. The findings have also revealed that the financial ratio and education/ vocational training jointly have a positive impact on SMEs financing. This is implicative of the fact that well-educated SMEs' owners/operators with a good business financial ratio tend to have better access to financial institutions' credit facilities.

Also, there is a strong significant interrelationship between the credit collection period, working capital, 
asset liquidity and the financial ratio. This means, the shorter asset liquidity, the better SMEs' working capital and financial ratios. SMEs' access to a loan has also been found to significantly vary from one Jos Metropolis's financial institution to another.

Based on the the above findings, the research study suggests that there is room for SMEs to increase the volume of their working capital and devise means to reduce the time necessary to collect all credit sales in order to meet banks' lending criteria. Also, SMEs' operators need to acquire relevant skills with respect to the type of the business activities they are engaged in, and also to train their staff in requisite skills so as to make their businesses attractive to banks' financing. The need to maintain the internal control system is also of the key importance for attracting loans from banks.

Finally, this study also suggests that financial institutions must be stable with respect to the criteria and mechanisms applied in the process of granting loans to SME businesses.

The risk management techniques employed by SMEs' operators determine the degree of their business vulnerability. Good risk management reduces the level of SME businesses exposure to risk, which forms a part of the criteria applied by financial institutions in the process of granting a loan to SMEs businesses. However, poor risk management techniques limit the extent of SMEs financing by a financial institution. The current study has left this important aspect unexamined, which future studies need to focus on. Also, even though a comprehensive review of the mechanisms used by financial institutions when determining SMEs' financial strength has been conducted, SMEs' financial reports should simultaneously be used in order to examine any bias in the criteria listed by financial institutions. It is recommended that future studies should look into this unexamined variation. The disconnection between financial institutions and the business financing of SMEs' operators/owners represents yet another asymmetric piece of information that needs to be investigated in future research studies so as to address the issue of SMEs financing.

\section{REFERENCES}

Adeyele, J. S., \& Omorokunwa, O. G. (2016). Risk Appetites and empirical survival patterns of SMEs in Nigeria. The Journal of Entrepreneurial Finance, 18(2).

Agyapong, D., Agyapong, G. K., \& Darfor, K. (2011). Criteria for assessing small and medium enterprises' borrowers in Ghana. International Business Research, 4(4), 132-138. doi:10.5539/ibr.v4n4p132

Asantey, J. O., \& Tengey, S. (2014). The determinants of bad loans in financing small and medium-size enterprises in the banking sector in Ghana: A factorial analysis approach. International Journal of Research in Business Management, 2(11), 13-26.

Bamfordt, C. D., \& Bruton, G. D. (2006). Small Business Management: A Framework Forn Success. Thomson: United States.

Bank of England. (2001). Quarterly report on small business statistics. London, UK: Bank of England, January: 1-46.

Beck, T., \& Demirguc-Kunt, A. (2006). Small and mediumsize enterprises: Access to finance as a growth constraint. Journal of Banking \& Finance, 30(11), 2931-2943. doi:10.1016/j. jbankfin.2006.05.009

Beck, T., Demirgüç-Kunt, A., Laeven, L., \& Maksimovic, V. (2006). The determinants of financing obstacles. Journal of International Money and Finance, 25(6), 932-952. doi. org/10.1016/j.jimonfin.2006.07.005

Haron, H., Said, S. B., Jayaraman, K. \& Ismail, I. (2013). Factors influencing Small Medium Enterprises (SMES) in obtaining loan. International Journal of Business and Social Science 4(15), 182-195.

Iyortsuun, A. S. (2017). An empirical analysis of the effect of business incubation process on firm performance in Nigeria. Journal of Small Business \& Entrepreneurship, 29(6), 433-459. doi.org/10.1080/08276331.2017.1376265

Kira, A. R., (2013). Determinants of financing constraints in East African countries' SMEs. International Journal of Business and Management, 8(8), 49-68. doi:10.5539/ijbm. v8n8p49

Levy, B. (1993). Obstacles to developing indigenous small and medium enterprises: An empirical assessment. The World Bank Economic Review, 7(1), 65-83. doi.org/10.1093/wber/7.1.65 
Nguyen, N., \& Luu, N. (2013). Determinants of financing pattern and access to formal - informal credit: The case of small and medium sized enterprises in Viet Nam. Journal of Management Research 5(2), 240-259. doi:10.5296/jmr.v5i2.3266

Obamuyi, T. M. (2007). An exploratory study of loan delinquency among small and medium enterprises (SMEs) in Ondo State of Nigeria. Labour and Management in Development, 8, 1-10

Organisation for Economic Co-operation and Development (OECD). (2015). New approaches to SMEs and entrepreneurship financing: Broadening the range of instruments. OECD Publishing.

Rand, J. (2007). Credit constraints and determinants of the cost of capital in Vietnamese manufacturing. Small Business Economics, 29(1), 1-13. doi.10.1007/s11187-005-1161-2

Saito, K., \& Villaneuva, D. (1981). Transactions cost of credit to small scale sector in the Philippines. Economic Development and Cultural Change, 29(3), 631-640.
Shikumo, D. H., \& Mwangi, M. (2016). Determinants of lending to small and medium enterprises by commercial banks in Kenya. IOSR Journal of Economics and Finance (IOSR-JEF), 7(4), 57-63. doi:10.9790/5933-0704045763

Singh, S., \& Janor, H. (2013). Determinants of SMEs financing pattern in India: A rotated factor analysis approach. International Journal of Economics and Management, 7(2), 314334.

Thanh, V., Cuong, T. T., Dung, B., \& Chieu, T. D. U. C. (2011). Small and Medium Enterprises Access to Finance in Viet Nam. Jakarta, Indonesia: Economic Research Institute for ASEAN and East Asia (ERIA).

The International Labour Organization (ILO). 2013). Training package on workplace risk assessment and management for small and medium-sized enterprises. Geneva, Switzerland: International Labour Organisation.

Waring, A. E., \& Glendon, A. I. (1998). Managing Risk. Andover, UK: Cengage Learning EMEA.

Received on $21^{\text {th }}$ July 2018 , after revision, accepted for publication on $22^{\text {nd }}$ August 2018 Published online on $27^{\text {th }}$ August 2018

Joshua Solomon Adeyele is a lecturer at the Department of Actuarial Science, University of Jos. Prior to his appointment in University of Jos, he has also lectured at Joseph Ayo Babalola University, and University of Benin. Joshua obtained his Master's and PhD degrees in University of Lagos and University of Ilorin respectively. He teaches Financial Mathematics, Actuarial Mathematics, Actuarial Valuation of Liabilities, Risk Management, and other courses in Insurance. The most important areas of his scientific research interest and work are Pensions and Other Benefits; Risk modeling and risk management; Survival models of SME; Life \& Health Insurance. 


\title{
KRITERIJUMI I MEHANIZMI FINANSIJSKIH INSTITUCIJA U FINANSIRANJU MALIH I SREDNJIH PREDUZEĆA U DRŽAVI PLATEAU, NIGERIJA
}

\author{
Joshua Solomon Adeyele \\ Departman za aktuarske nauke, Univerzitet u Jos-u, Nigerija
}

\begin{abstract}
Činjenica da mala i srednja preduzeća (MSP) nemaju pristup sredstvima finansijskih institucija identifikovana je kao jedan od najvećih problema koji ograničava širenje poslovanja tih preduzeća. Ova studija ima za cilj da proceni kriterijume i mehanizme koje finansijske institucije koriste prilikom odobravanja kredita MSP. Podatke smo dobili od relevantnih finansijskih institucija i iste smo analizirali primenjujući različite statističke alate. Jedan od nalaza do kojih smo došli pokazuje da finansijski pokazatelj i sistem interne kontrole objašnjavaju 28,7\% uslova za odobravanje kredita MSP. Slično tome, dobar obrtni kapital i lakoća konverzije sredstava objašnjavaju 94,5\% kriterijuma koje finansijske institucije primenjuju prilikom odobravanja kredita/pozajmica MSP. Obrazovni profil zaposlenih u MSP, takođe, značajno utiče na izbor MSP koja će finansijske institucije finansirati. Na osnovu tih nalaza, u studiji se ukazuje na činjenicu da postoji potreba za usaglašavanje poslovnih aktivnosti zaposlenih u MSP sa kriterijumima za odobravanje kredita, koje primenjuju finansijske institucije.
\end{abstract}

Ključne reči: mala i srednja preduzeća, pokazatelj likvidnosti, sistem interne kontrole, pristup pozajmicama, finansijska institucija

JEL Classification: C21, H81 